The Sex of Things 



\title{
The Sex of Things
}

Gender and Consumption

in Historical Perspective

\author{
EDITED BY \\ Victoria de Grazia, \\ with Ellen Furlough \\ INTRODUCTIONS BY \\ Victoria de Grazia
}

UNIVERSITY OF CALIFORNIA PRESS

Berkeley Los Angeles London 


\author{
University of California Press \\ Berkeley and Los Angeles, California \\ University of California Press, Ltd. \\ London, England \\ (C) 1996 by \\ The Regents of the University of California
}

\title{
Library of Congress Cataloging-in-Publication Data
}

The sex of things : gender and consumption in historical perspective / edited by Victoria de Grazia, with Ellen Furlough; introductions by Victoria de Grazia. p. $\mathrm{cm}$.

Includes bibliographical references and index.

ISBN o-520-20034-9 (alk. paper). — ISBN 0-520-20197-3 (pbk. : alk. paper)

1. Consumer behavior-Sex differences-History. 2. Consumption

(Economics)-Social aspects-History. I. De Grazia, Victoria. II. Furlough, Ellen, 1953-.

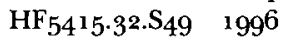

$65^{8} .8^{\prime} 34^{8}-\mathrm{dc} 2 \mathrm{O}$

95-37354

Printed in the United States of America

987654321

The paper used in this publication meets the minimum requirements of American National Standard for Information Sciences-Permanence of Paper for Printed Library Materials, ANSI Z39.48-1984.

An earlier version of chapter 11 was published in Rob Kroes, Robert Rydell, and Kurt Bosscher, eds., Cultural Transmissions and Receptions: American Mass Culture in Europe (Amsterdam: VU University Press, 1993), 84-99. A shorter version of chapter 13 appears in Rachel Bowlby, Still Crazy after All These Years (London: Routledge, 1992). 